STUDI

FRANCESI

\section{Studi Francesi}

Rivista quadrimestrale fondata da Franco Simone

165 (LV | III) | 2011

LA RAPPRESENTAZIONE DELLA MADRE NELLA

LETTERATURA FRANCESE DEL NOVECENTO a cura di Dario Cecchetti e Michele Mastroianni

\title{
Max Engammare, Une dédicace inconnue de Calvin à Myconius sur la "Supplex Exhortatio" de 1543
}

Filippo Fassina

\section{(2) OpenEdition \\ Journals}

Edizione digitale

URL: http://journals.openedition.org/studifrancesi/4958

DOI: 10.4000/studifrancesi.4958

ISSN: 2421-5856

Editore

Rosenberg \& Sellier

Edizione cartacea

Data di pubblicazione: 1 décembre 2011

Paginazione: 629

ISSN: 0039-2944

Notizia bibliografica digitale

Filippo Fassina, «Max Engammare, Une dédicace inconnue de Calvin à Myconius sur la "Supplex Exhortatio" de 1543», Studi Francesi [Online], 165 (LV | III) | 2011, online dal 30 novembre 2015, consultato il 13 janvier 2021. URL: http://journals.openedition.org/studifrancesi/4958 ; DOI: https:// doi.org/10.4000/studifrancesi.4958

Questo documento è stato generato automaticamente il 13 janvier 2021.

\section{(†) $\ominus$

Studi Francesi è distribuita con Licenza Creative Commons Attribuzione - Non commerciale - Non opere derivate 4.0 Internazionale. 


\title{
Max Engammare, Une dédicace inconnue de Calvin à Myconius sur la "Supplex Exhortatio" de 1543
}

\author{
Filippo Fassina
}

NOTIZIA

MAX ENGAMMARE, Une dédicace inconnue de Calvin à Myconius sur la "Supplex Exhortatio" de 1543, «Bibliothèque d'Humanisme et Renaissance», LXXI, 3 (2009), pp. 535-539.

1 Nel presente contributo, vengono descritti i rapporti epistolari fra Calvino e Myconius relativi alla Supplex Exhortatio che Calvino scrisse nel 1543 e inviò a Myconius l'anno successivo. Di quest'opera possediamo infatti il frontespizio (qui riprodotto) contenente la dedica, conservato alla Bayerische Staatsbibliothek di Monaco e tale documento permette all'A. di chiarire meglio il rapporto fra i due eruditi nella metà del Cinquecento. 